\title{
Friedrich Nietzsche's Philosophy of Life and its Contradiction in Milan Kundera's Novel Unbearable Lightness of Being
}

\author{
Somana Fatima \\ Ph. D. (Linguistics) Aligarh Muslim University, Aligarh \\ M.A. (English) English and Foreign Languages University, Hyderabad
}

\begin{abstract}
This paper argues about the Friedrich Nietzsche's different Philosophies of life ("existentialism", and "the death of God") and its concept of the eternal recurrence. Whereas, Milan Kundera's Philosophy of life is that each person has only one life to live, and that whatever occurs in life occurs only once and never again. The aim and objective of this paper is to highlight the concept of eternal recurrence and its contradiction in the novel Unbearable Lightness of Being. This paper possesses the methodology of "Perspectivism"which says it is just the different perspective towards life; there is nothing called good or bad, right or wrong, black and white. Perspectivism is the idea that there is no singular truth in the world. Parmenides saw the world divided into pairs of opposites: light/darkness, fineness/coarseness etc. One half of the opposition he called positive (light, fineness, warmth, being), the other negative. Parmenides responded that lightness is positive, weight negative. This paper also argues between the lightness and weight of life.
\end{abstract}

Keywords: Nietzsche Philosophy of life, Existentialism, "eternal recurrence”, Milan Kundera's reverse viewpoint, Unbearable Lightness of Being: Characters and theme (lightness and weight) and Perspectivism. Parmenides definition of positives and negatives

\section{Introduction}

Much of the philosophical content of The Unbearable Lightness of Being begins with the idea of eternal return, or the notion that our lives are repeated ad infinitum throughout a circular passing of time. Kundera rejects the idea of eternal return and argues that our lives occur only once, and that time is in fact linear, not circular. Because our lives occur only once, they fail to gain weight or significance, and are unbearably light. Kundera compares human time, which is linear, to animal time and idyllic time in biblical Paradise, which he argues is circular. Kundera claims that happiness is the longing for repetition - the longing for circular time. We're out of luck, then, since we cannot experience time this way. Instead, we struggle to give our lives meaning and to be happy when neither is strictly possible. (Article. 2009)

Friedrich Nietzsche and Milan Kundera's Philosophy:

Friedrich Nietzsche was a German philosopher, essayist, and cultural critic. His writings on truth, morality, language, aesthetics, cultural theory, history, nihilism, power, consciousness, and the meaning of existence have exerted an enormous influence on western philosophy and intellectual history. Whereas, Milan Kundera manifests the latest stage of his personal philosophy. Some of philosophy includes exile, identity, and life beyond the border (beyond love, beyond art, beyond seriousness), history as continual return, and the pleasure of a less "important" life. (François Ricard, 2003)

Nietzsche speaks of "the death of God," and foresees the dissolution of traditional religion and metaphysics. He is engaged in a positive program to reaffirm life, and so he is called for a radical, naturalistic rethinking of the nature of human existence, knowledge, and morality.

Nietzsche claimed the exemplary human being must craft his/her own identity through self-realization and do so without relying on anything transcending that life - such as God or a soul. This way of living should be affirmed even were one to adopt, most problematically, a radical vision of eternity, one suggesting the "eternal recurrence" of all events. On the other hand, Kundera assumed that eternal return were impossible, humankind would experience an "absolute absence of burden," and this would "[cause] man to be lighter than air" in his lack of weight of meaning. (François Ricard, 2003)

Friedrich Nietzsche's Idea of Eternal Recurrence and Milan Kundera's Reverse Viewpoint

Nietzsche explains the idea of eternal recurrence by saying: the greatest weight-What, if some day or night a demon were to steal after you into your loneliest loneliness and say to you: "This life as you now live it and have lived it, you will have to live once more and innumerable times more; and there will be nothing new in it, but every pain and every joy and every thought and sigh and everything unutterably small or great in your life will have to return to you, all in the same succession and sequence-even this spider and this moonlight between the trees, and even this moment and I myself. The eternal hourglass of existence is turned upside down again and again, and you with it, speck of dust!" (Nietzsche 2001: 341).

"What if," wonders Nietzsche, the thought took hold of us? Here, the conceptualization of eternal recurrence, thus, coincides with questions regarding its impact: "how well disposed would you have to become to yourself and to life to crave nothing more fervently than this ultimate eternal confirmation and seal?" (Dale Wilkerson, Internet Encyclopedia of Philosophy)

The actual announcement of the 'death of God', have completely missed madman's woeful mourning which follows the announcement. "'Where is God?' he cried; 'I'll tell you! We have killed him - you and I! We are all his 


\section{International Journal of Science and Research (IJSR) \\ ISSN (Online): 2319-7064}

Index Copernicus Value (2016): 79.57 | Impact Factor (2015): 6.391

murderers. But how did we do this? How were we able to drink up the sea? Who gave us the sponge to wipe away the entire horizon? What were we doing when we unchained this earth from its sun? Where is it moving? Where are we moving to? Away from all suns?" (Nietzsche 2001:125).

The above sentences are very far from constituting a cheerful declaration: no one is happy here! Nietzsche's atheism has nothing to do with the naive atheism of others (for example Sartre) who rush to affirm their freedom as if their petty individuality were able to fill the vast empty space left by the absence of God. Nietzsche is not naive and because he is not naive he is rather pessimistic. (Nietzsche 2001)

\section{Literary Works of Kundera}

He is best known as the author of The Unbearable Lightness of Being, The Book of Laughter and Forgetting, and The Joke. Kundera has written in both Czech and French. He revises the French translations of all his books; these therefore are not considered translations but original works. His other works are Life is Elsewhere, Immortality and The Festival of Insignificance.

\section{Unbearable Lightness of Being: Characters}

Tomas is one of four main characters born frankly of images in Mr. Kundera's mind. All of them to one extent or another enact the paradox of choices that are not choices, of courses of action that are indistinguishable in consequence from their opposite. He shows us Sabina, a painter, as she is deciding whether or not to keep her current lover. Franz, a university professor, is physically strong. If he used his strength on her and ordered her about, Sabina knows she wouldn't put up with him for five minutes. But he is gentle, and because she believes physical love must be violent she finds Franz dull. Either way, whatever Franz does, she will have to leave him.

Mr. Kundera says Sabina lives by betrayal, abandoning family, lovers and, finally, country, in a way that condemns her to what he calls a "lightness of being," by which by contrast, his fourth character, Tereza, the loyal wife of Tomas, suffers an unflagging love for her philandering husband that finally is responsible for his ruin, because it's her unwillingness to live in exile that brings him back to his fate in Czechoslovakia he means a life so lacking in commitment or fidelity or moral responsibility to anyone else as to be unattached to the real earth.after he has set himself up nicely in a Swiss hospital. Thus, Tereza, the exact opposite of Sabina in commitment and fidelity and rootedness to the real earth, sinks under an unbearable moral burden, weight and lightness, in the Kunderian physics, adding up to the same thing.

\section{Main Philosophy of Unbearable Lightness of Being: Lightness and Weight \\ Lightness and weight both get linked to a philosopher, a philosophy of life, and several characters. The ancient Greek Paremenides, mentioned in the opening pages of the novel, is a philosopher of lightness to whom weight is negative. Practically, accepting the lightness of being means accepting a certain lack of ultimate meaning in life, and living for}

momentary beauty. While both Tomas and Sabina are characterized by lightness, Sabina is the more extreme example as she consistently refuses to be tied down. Tomas, on the other hand, ultimately returns to Tereza and Prague.

Kundera associates heaviness with Nietzsche and the philosophy of eternal return. Kundera does not believe eternal return exists, and argues that man only has the opportunity to try one path, and hence has no point of comparison or meaning. Instead, those characters that are heavy cannot accept this unbearable lightness of being, and seek to attach a meaning and weight to what they consider important in life. Tereza and Franz are both heavy characters. Tereza is heavy emotionally and cannot cope with the lightness around her, and is driven nearly to insanity. Franz, interpreting all the events of his life as heavy, is led to an early and unnecessary death.

Lightness versus weight is the key dichotomy of The Unbearable Lightness of Being, a paradox that cannot be resolved. None of the four characters ultimately seem to find a solution. It is noteworthy that of the four, Sabina is the only one living at the end of the book; however, not even she is necessarily happy or fulfilled or sure of her life choices. (Sparknotes)

\section{The Unbearable Lightness of Being is an exploration of the concept of Lightness}

Kundera uses Friedrich Nietzsche's doctrine of the Eternal Return to illustrate Lightness. Eternal Return dictates that all things in existence recur over and over again for all eternity. This is to say that human history is a preset circle without progress, the same events arising perpetually and doomed never to alter or to improve. Existence is thus weighty because it stands fixed in an infinite cycle. This weightiness is "the heaviest of burdens", for "if every second of our lives recurs an infinite number of times, we are nailed to eternity as Jesus Christ was nailed to the cross." At the same time, it is necessary for any event to occur in the cycle of events exactly as it has always occurred for the cycle to be identical; consequently, everything takes on an eternally fixed meaning. This fact prevents one from believing things to be fleeting and worthless.

The inverse of this concept is Kundera's "unbearable lightness of being." Assuming that eternal return were impossible, humankind would experience an "absolute absence of burden," and this would "[cause] man to be lighter than air" in his lack of weight of meaning. Something which does not forever recur has its brief existence, and, once it is complete, the universe goes on existing, utterly indifferent to the completed phenomenon. "Life which disappears once and for all, which does not return" writes Kundera, is "without weight...and whether it was horrible, beautiful, or sublime...means nothing." Each life is insignificant; every decision does not matter. Since decisions do not matter, they are "light": they do not tie us down. However, at the same time, the insignificance of our decisions - our lives, or being - is unbearable. Hence, "the unbearable lightness of being." On the other hand, eternal existence would demand of us strict adherence to prescript rules and laws; a sense of duty and rigorous morality.

\section{Volume 6 Issue 12, December 2017}




\section{International Journal of Science and Research (IJSR) \\ ISSN (Online): 2319-7064}

Index Copernicus Value (2016): 79.57 | Impact Factor (2015): 6.391

"What then shall we choose? Weight or lightness?" Kundera notes that this is not a new question. Parmenides posed it in the sixth century BC. He saw the world divided into pairs of opposites: light/darkness, fineness/coarseness etc. One half of the opposition he called positive (light, fineness, warmth, being), the other negative. We might find this division into positive and negative poles simple except for one difficulty: which one is positive, weight or lightness? Parmenides responded that lightness is positive, weight negative. Kundera then questions "Was he correct or not?" The lightness/weight opposition remains the most ambiguous of all. Kundera then asks, should one live with weight and duty or with lightness and freedom? In Nietzschean terms, weight is life-affirming in that to live with positive intensity is to live in a way you'd be prepared to repeat. The emptiness of Sabina's life in 'The Unbearable Lightness Of Being', and that she wanted to "die in lightness" — which is to say that she is indifferent to her life - shows that she would not want to repeat her life and would not accept an eternal return. (Philosophy: Lightness)

The heaviest of burdens crushes us, we sink beneath it, it pins us to the ground. But ... the heavier the burden, the closer our lives come to the earth, the more real and truthful they become. Conversely, the absolute absence of a burden causes a man to be lighter than air, to soar into the heights, take leave of the earth and his earthly being, and become only half real, his movements as free as they are insignificant. (Kundera 1999: 5)

The problem with the light life is that its meaninglessness. If everything happens only once, it might as well not have happened at all. In response, all one can do is live for beauty and pleasure. Yet, paradoxically, we find the insignificance of our lives unbearable - the unbearable lightness of being. If life lacks objective meaning, nihilism beckons, unless we act as if our actions eternally recur. But then the heaviness of our actions and choices crushes us under their weight. (Kundera 1999: 5)

Despite these conundrums the main characters in his novel who embrace the heaviness of life and love die happy, while those who live lightly suffer the unbearable lightness of being. This suggests that heaviness is better after all. Still nothing is eternal for Kundera, and if there were, our lives and choices would be too burdensome. Perhaps the fact that some of his characters find love is enough, but nothing matters ultimately. In the end nihilism is, for conscious beings, both true and unbearable. A heavy life crushes us; a light life is unbearable.

As for me, I think we ought to consider life significant, but not too significant; light but not too light. Here it is in simple form. (Kundera 1999)

\section{The Unbearable Lightness of Being-Nietzsche, Parmenides, And Milan Kundera \\ Milan Kundera's The Unbearable Lightness of Being opens with a philosophical discussion of lightness versus heaviness. Kundera contrasts Nietzsche's philosophy of eternal return, or of heaviness, with Parmenides's understanding of life as light. Kundera wonders if any meaning or weight can be attributed to life, since there is no}

eternal return: if man only has the opportunity to try one path, to make one decision, he cannot return to take a different path, and then compare the two lives. Without the ability to compare lives, Kundera argues, we cannot find meaning; where meaning should exist we find only an unbearable weightlessness (Sparknotes)

For Nietzsche the concept of Eternal Return was frightening and abhorrent. There could be nothing worse than an endless cycle of recurring events. Nothing is ever new, and whatever exists has existed before - not just once but a million million times. The world never reaches a final state. There is no finality of time; time is infinite. There is no beginning to time. It is cyclical, non-linear, bent into a circle.

Heinrich Heine whom Nietzsche greatly admired said: "Time is infinite, but the things in time, the concrete bodies are finite.... Now, however long a time may pass, according to the eternal laws governing the combinations of this eternal play of repetition, all configurations that have previously existed on this earth must yet meet, attract, repulse, kiss, and corrupt each other again..

Nietzsche's answer to this philosophical nightmare was acting outside morality, beyond good and evil; and the only validation of such a meaningless life is the expression of individual will.

Parmenides saw the world divided into pairs of opposites: light/darkness, fineness/coarseness etc. One half of the opposition he called positive (light, fineness, warmth, being), the other negative. We might find this division into positive and negative poles simple except for one difficulty: which one is positive, weight or lightness? Parmenides responded that lightness is positive, weight negative. What Parmenides ends up deducing is that "what is" is ungenerated and unperishable, unchanging, perfect, one, and continuous.

Under these conditions 'lightness' is the only logical descriptor of reality. If reality is one, indivisible, and perfect; then individual actions are meaningless. There are no Supermen in Parmenides' conception of life; but no need for them. One can drift lightly from one piece of reality to another without commitment, anxiety, or wonder.

Kundera ponders this dilemma. Do we live in a world of meaning, purpose, commitment, and responsibility? Or do we live in one without them, free to wander in a delightful smorgasbord of life?

Hinduism and Islam posits a third way, distinct from both Nietzsche and Parmenides but in many ways similar to them. The world is nothing but maya/ duniya or illusion, say Hindus/ Muslim, and any attachment to it is an unnecessary diversion from the path of Enlightenment. Only when one finally divorces himself from this illusory 'reality' can he become a fully mature spiritual being, subsumed into an eternal and universal consciousness.

\section{Volume 6 Issue 12, December 2017}




\section{International Journal of Science and Research (IJSR) \\ ISSN (Online): 2319-7064 \\ Index Copernicus Value (2016): 79.57 | Impact Factor (2015): 6.391}

Final Conclusion: Philosophy of Perspectivism

Nietzsche talks about 'perspective' when he is relating beliefs to our values. He uses the word 'interpretation' to mean a belief about something as if it is like this or that. An interpretation is an understanding of the world from a particular perspective; and so interpretations, like perspectives, relate back to our values. Different perspectives are defined by different values; differences in belief are not themselves enough. Two people with different religious beliefs, for instance, may occupy the same perspective if their beliefs reflect the same underlying set of values. (Nietzsche's Perspectivism)

\section{References}

[1] Article. Nietzsche Eternal Recurrence in Kundera's Novel Unbearable Lightness of Being. 29 Nov. 2009.

[2] François Ricard, 2003. Le Dernier Après-midi d'Agnès : essai sur l'œuvre de Milan Kundera

[3] Dale Wilkerson, The Internet Enclyclopedia of Philosophy. University of North Texas, Denton U. S. A.

[4] Nietzsche Friedrich. 2001. The Gay Science Cambridge: Cambridge University Press.

[5] Question About Time

[6] https://www.shmoop.com/unbearable-lightness-ofbeing/time-theme.html

[7] https://www.goodreads.com/author/show/6343.Milan_K undera

[8] Schmadel, Lutz D. International Astronomical Union (2003). Dictionary of minor planet names. Berlin; New York: Springer-Verlag. p. 594. ISBN 978-3-540-002383. Retrieved 29 July 2012.

[9] The Unbearable Lightness of Being, Novel in seven parts, written in 1982, first published in French in Spring of 1984.

[10] Four Characters under two Tyrannies Review by E.L. Doctorow

[11] http://www.kundera.de/english/Bibliography/The_Unbe arable_Lightness_of_Be/the_unbearable_lightness_of_b e.html

[12] http://www.sparknotes.com/lit/unbearablelightness/the mes.html

[13] https://en.wikipedia.org/wiki/Lightness_(philosophy)

[14] http://cw.routledge.com/textbooks/alevelphilosophy/dat a/A2/Nietzsche/NietzschePerspectivism.pdf 